\title{
Author Correction: RNAs coordinate nuclear envelope assembly and DNA replication through ELYS recruitment to chromatin
}

\author{
Antoine Aze ${ }^{1}$, Michalis Fragkos ${ }^{1,3}$, Stéphane Bocquet ${ }^{1}$, Julien Cau $^{2}$ \& Marcel Méchali ${ }^{1}$
}

Correction to: Nature Communications (2017) https://doi.org/10.1038/s41467-017-02180-1, Article published online 14 December 2017

In the original version of this Article, the affiliation details for Antoine Aze, Michalis Fragkos, Stéphane Bocquet, Julien Cau and Marcel Méchali incorrectly omitted 'CNRS and the University of Montpellier'. This has now been corrected in both the PDF and HTML versions of the Article.

Published online: 05 February 2018

\begin{abstract}
(c) (i) Open Access This article is licensed under a Creative Commons Attribution 4.0 International License, which permits use, sharing, adaptation, distribution and reproduction in any medium or format, as long as you give appropriate credit to the original author(s) and the source, provide a link to the Creative Commons license, and indicate if changes were made. The images or other third party material in this article are included in the article's Creative Commons license, unless indicated otherwise in a credit line to the material. If material is not included in the article's Creative Commons license and your intended use is not permitted by statutory regulation or exceeds the permitted use, you will need to obtain permission directly from the copyright holder. To view a copy of this license, visit http://creativecommons.org/licenses/by/4.0/.
\end{abstract}

(C) The Author(s) 2018

\footnotetext{
${ }^{1}$ Institute of Human Genetics, UMR 9002, CNRS and the University of Montpellier, Replication and Genome Dynamics, 141 rue de la Cardonille, 34396 Montpellier, France. ${ }^{2}$ Institute of Human Genetics, UMR 9002, CNRS and the University of Montpellier, Montpellier RIO Imaging, 141 rue de la Cardonille, 34396 Montpellier, France. ${ }^{3}$ Present address: Institut Gustave Roussy, Genetic Stability and Oncogenesis Department, 39 rue Camille Desmoulins, 94805 Villejuif, France. Antoine Aze and Michalis Fragkos contributed equally to this work. Correspondence and requests for materials should be addressed to A.A. (email: antoine.aze@igh.cnrs.fr) or to M.Méc. (email: marcel.mechali@igh.cnrs.fr)
} 